\title{
Serotonin Activates Catecholamine Neurons in the Solitary Tract Nucleus by Increasing Spontaneous Glutamate Inputs
}

\author{
Ran Ji Cui, ${ }^{\star}$ Brandon L. Roberts, ${ }^{\star}$ Huan Zhao, Mingyan Zhu, and Suzanne M. Appleyard \\ Program in Neuroscience, Department of Veterinary Comparative Anatomy, Physiology and Pharmacology, Washington State University, Pullman, \\ Washington 99164
}

\begin{abstract}
Serotonin (5-HT) is a critical neurotransmitter in the control of autonomic functions. 5- $\mathrm{HT}_{3}$ receptors participate in vagal afferent feedback to decrease food intake and regulate cardiovascular reflexes; however, the phenotype of the solitary tract nucleus (NTS) neurons involved is not known. $\mathrm{A}_{2} / \mathrm{C}_{2}$ catecholamine $(\mathrm{CA})$ neurons in the NTS are directly activated by visceral afferents and are important for the control of food intake and cardiovascular function, making them good candidates to respond to and mediate the effects of serotonin at the level of the NTS. This study examines serotonin's effects on NTS-CA neurons using patch-clamp techniques and transgenic mice expressing an enhanced green fluorescent protein driven by the tyrosine hydroxylase (TH) promoter (TH-EGFP) to identify catecholamine neurons. Serotonin increased the frequency of spontaneous glutamate excitatory postsynaptic currents (sEPSCs) in $>90 \%$ of NTS-THEGFP neurons, an effect blocked by the 5- $\mathrm{HT}_{3}$ receptor antagonist ondansetron and mimicked by the $5-\mathrm{HT}_{3}$ receptor agonists SR5227 and mCPBG. In contrast, $5-\mathrm{HT}_{3}$ receptor agonists increased sEPSCs on a minority $(<30 \%)$ of non-TH neurons. $5-\mathrm{HT}_{3}$ receptor agonists increased the frequency, but not the amplitude, of mini-EPSCs, suggesting that their actions are presynaptic. $5-\mathrm{HT}_{3}$ receptor agonists increased the firing rate of TH-EGFP neurons, an effect dependent on the increased spontaneous glutamate inputs as it was blocked by the ionotropic glutamate antagonist NBQX, but independent of visceral afferent activation. These results demonstrate a cellular mechanism by which serotonin activates NTS-TH neurons and suggest a pathway by which it can increase catecholamine release in target regions to modulate food intake, motivation, stress, and cardiovascular function.
\end{abstract}

\section{Introduction}

Serotonin (5-HT) is a neurotransmitter that influences a broad range of physiological processes and behaviors, including pain, mood, cardiovascular function, and food intake. Serotonin has extensive effects throughout the CNS; however, an important site of action for the regulation of cardiovascular function and food intake is the nucleus of the solitary tract (NTS) (Merahi et al., 1992; Raul, 2003; Hayes and Covasa, 2006b; Lam et al., 2009). The NTS is the primary site through which visceral afferent information enters the brain and activates second order neurons via glutamatergic synapses (Andresen and Kunze, 1994; Saper, 2002; Berthoud, 2008; Grill and Hayes, 2009). Many types of serotonin receptors are expressed in the NTS, including the $5-\mathrm{HT}_{3}$ receptor $\left(5-\mathrm{HT}_{3} \mathrm{R}\right)$ subtype, which are expressed on vagal afferent terminals (Pratt and Bowery, 1989; Leslie et al., 1990; Merahi et al., 1992; Huang et al., 2004) where they have been shown to modu-

Received March 16, 2012; revised Aug. 22, 2012; accepted Aug. 29, 2012.

Author contributions: R.J.C., B.L.R., and S.M.A. designed research; R.J.C., B.L.R., H.Z., and M.Z. performed research; R.J.C., B.L.R., H.Z., and M.Z. analyzed data; B.L.R. and S.M.A. wrote the paper.

This work was supported by a grant from the National Institutes of Health (DK083452). The content is solely the responsibility of the authors and does not necessarily represent the official views of the National Institute of Diabetes and Digestion and Kidney disease or the National Institutes of Health. We thank Xiaojun Li for her technical assistance and Dr. James Peters for his helpful comments on this manuscript.

*R.J.C. and B.L.R. contributed equally to this work.

Correspondence should be addressed to Suzanne M. Appleyard, Department of Veterinary Comparative Anatomy, Physiology, and Pharmacology (VCAPP), Program in Neuroscience, Washington State University, 100 Dairy Road, Pullman, WA 99164. E-mail: appleyas@vetmed.wsu.edu.

DOI:10.1523/JNEUROSCI.1372-12.2012

Copyright $\odot 2012$ the authors $\quad 0270-6474 / 12 / 3216530-09 \$ 15.00 / 0$ late glutamate release (Glaum et al., 1992; Wan and Browning, 2008; Takenaka et al., 2011). Activation of $5-\mathrm{HT}_{3} \mathrm{Rs}$ in the NTS contributes both to termination of a meal (Hayes and Covasa, 2006a), severe anorexia (Wu et al., 2012), and cardiovascular reflexes (Jeggo et al., 2005; Jordan, 2005; Weissheimer and Machado, 2007; Ramage and Villalon, 2008), but the phenotype of the NTS neurons regulated by serotonin is not known.

$\mathrm{A}_{2} / \mathrm{C}_{2}$ catecholamine neurons in the NTS (NTS-CA neurons) are important for the control of many behaviors influenced by serotonin, as interfering with the function of NTS-CA neurons affects food intake, cardiovascular reflexes, and reward (Simon et al., 1985; Kubo et al., 1990; Itoh and Bunag, 1993; Olson et al., 2006; Rinaman, 2011). Ingestion of a meal, gastric distention, and anorexigens (Monnikes et al., 1997; Willing and Berthoud, 1997; Rinaman et al., 1998; Blevins et al., 2008; Williams et al., 2008; Lam et al., 2009) all increase c-fos expression in NTS-CA neurons, as do changes in blood pressure (Chan and Sawchenko, 1998), noxious stimuli (Jin et al., 1994), immune challenge (Lacroix and Rivest, 1997), and opioid withdrawal (Laorden et al., 2000). NTS-CA neurons project to numerous brain regions, including the hypothalamus, amygdala, nucleus accumbens, and brainstem nuclei (Sawchenko and Swanson, 1981; Riche et al., 1990; Wang et al., 1992; Petrov et al., 1993; Ueta et al., 2000; Reyes and Van Bockstaele, 2006; Travagli et al., 2006; Balcita-Pedicino and Rinaman, 2007), and release of catecholamines at these sites affects a broad number of behaviors, including food intake, reward, stress, and cardiovascular function (Leibowitz et al., 1988; Cole and Sawchenko, 2002; Smith and Aston-Jones, 2008). 
Therefore, one potential mechanism by which serotonin could alter these behaviors is by increasing the activity of NTS-CA neurons.

We have previously demonstrated that NTS-CA neurons are second order neurons that receive direct glutamatergic inputs from visceral afferent fibers, resulting in large-amplitude EPSCs that almost always elicit action potentials at afferent firing frequencies $<5 \mathrm{~Hz}$ (Appleyard et al., 2007). NTS-CA neurons also receive spontaneous (action potential-independent) glutamate inputs whose frequency can be modulated to impact their basal firing rate (Cui et al., 2011). The goal of these studies is to determine what effect serotonin has on NTS-CA neuronal activity and the underlying mechanism(s) involved.

\section{Materials and Methods}

NTS slices. Hindbrains of both male and female TH-EGFP mice (6-20 weeks old) were prepared as described previously (Appleyard et al., 2007). All animal procedures were conducted with the approval of the Animal Care and Use Committees at Washington State University (Pullman, WA) and in accordance with the U.S. Public Health Service Policy on Humane Care and Use of Laboratory Animals (PHS Policy) and the National Institutes of Health Guide for the Care and Use of Laboratory Animals (NIH Guide). The hindbrain was removed and placed for $1 \mathrm{~min}$ in cold $\left(0-4^{\circ} \mathrm{C}\right)$ artificial cerebral spinal fluid composed of (in mM): 125 $\mathrm{NaCl}, 3 \mathrm{KCl}, 1.2 \mathrm{KH}_{2} \mathrm{PO}_{4}, 1.2 \mathrm{MgSO}_{4}, 25 \mathrm{NaHCO}_{3}, 10$ dextrose, $2 \mathrm{CaCl}_{2}$, and bubbled with $95 \% \mathrm{O}_{2} / 5 \% \mathrm{CO}_{2}$. The osmolarity was adjusted to $301-$ 305 mOsm using dextrose. The medulla was trimmed to a $2 \mathrm{~cm}$ block (rostral-caudal) centered on the obex. A wedge of tissue was removed from the ventral surface to align the solitary tract (ST) with the cutting plane when mounted in a vibrating microtome (Leica VT-1000S). Slices (250 $\mu \mathrm{m}$ thick) cut with a sapphire knife (Delaware Diamond Knives) contained the ST in the same plane as the NTS. Slices were submerged in a perfusion chamber and all recordings were performed at $31-35^{\circ} \mathrm{C}$ and $\mathrm{pH}$ 7.4. Neurons were visualized using an upright microscope (Olympus BX51). Recording electrodes were filled with a solution (in mM): $10 \mathrm{NaCl}$, $130 \mathrm{~K}$ gluconate, 11 EGTA, $1 \mathrm{CaCl}_{2}, 2 \mathrm{MgCl}_{2}, 10 \mathrm{HEPES}, 2 \mathrm{NaATP}, 0.2$ NaGTP, pH 7.3, 297-301 mOsm. Neurons were recorded from NTS within $200 \mu \mathrm{m}$ rostral or caudal from obex and medial to the ST-medial NTS. Patch electrodes, 3-5 M $\Omega$, were guided to neurons using differential interference contrast (DIC) optics illuminated with infrared light (Olympus B51). Voltage-clamp recordings were made with an Axopatch 700B (Molecular Devices), Digidata 1440A digitizer (Molecular Devices), and pClamp 10 software (Molecular Devices). Only neurons with holding currents not exceeding $100 \mathrm{pA}$ at $\mathrm{V}_{\mathrm{H}}=-60 \mathrm{mV}$ for the $15 \mathrm{~min}$ control period (input resistance $>150 \mathrm{M} \Omega$ ) were studied further. Series resistance was monitored throughout the recordings, and neurons were not included in further analysis if it exceeded $20 \mathrm{M} \Omega$ or drifted $>25 \%$. Series resistance did not differ between control (ACSF) and treatment. Synaptic currents were evoked with an ultrafine concentric bipolar stimulating electrode (50 $\mu \mathrm{m}$ inner diameter; Frederick Haer Company) placed on the ST $1-3 \mathrm{~mm}$ from the recording electrode. Electrical stimuli were delivered from an isolated programmable stimulator (ISO-Flex stimulator with Master-8, A.M.P.I.) triggered to deliver a burst of stimuli $(5-50 \mathrm{~Hz})$. Current-clamp recordings were made at resting membrane potentials, and current injections were not used to hold the membrane at set potentials. All membrane potentials reported were corrected for junction potential $(14 \mathrm{mV})$. All drugs were obtained from Tocris Cookson or Sigma.

Statistics. All data are presented as averages \pm SEM. Statistical comparisons of drug effects between groups (e.g., non-catecholamine and catecholamine) were made using one-way ANOVA with Tukey's or Bonferroni post hoc analysis and Fisher's exact test where appropriate (see Results; Mintab 16, GraphPad). The Kolmogorov-Smirnov test (KS test) was used to determine the significance of the drug effect for individual neurons when analyzing the sEPSC and miniature EPSC (mEPSC) data (mini analysis, Synaptosoft). $p<0.05$ indicated significant differences.

\section{Results}

\section{Serotonin increases frequency of spontaneous glutamate inputs onto TH-EGFP neurons}

All TH-EGFP neurons were easily visualized and identified for recordings (Figure $1 A$ ). We have previously shown a $>88 \%$ colocalization of EGFP with TH in the medial and caudal NTS of these mice (Appleyard et al., 2007; Cui et al., 2011). As reported previously (Appleyard et al., 2007) we found that $90 \%$ of the TH-EGFP neurons studied were directly activated by ST afferents, making them second order neurons. Application of $30 \mu \mathrm{M}$ serotonin increased the frequency of spontaneous EPSCs in all TH-EGFP neurons tested (Fig. $1 B, C, D ; p<0.05$, KS test, $n=6$ ). The basal frequency of sEPSCs in TH-EGFP neurons was variable, ranging from 0.2 to $12.5 \mathrm{~Hz}$, as was previously reported (Cui et al., 2011), suggesting that these neurons receive varying levels of basal glutamate tone, at least in the horizontal slice. Bath application of serotonin increased the frequency of sEPSCs from $1.9 \pm 0.63 \mathrm{~Hz}$ in control (ACSF) to $10.56 \pm 2.45 \mathrm{~Hz}$ (5-HT) $(n=$ $6)$. The effects of serotonin were reversed after a $5 \mathrm{~min}$ wash (ACSF) (Fig. $1 F, n=4$ ). Serotonin did not significantly change the average amplitude of sEPSCs (Figure $1 E$ ). On average, serotonin did not significantly effect sEPSC frequency at concentrations of $1 \mu \mathrm{M}(239 \pm 78 \%, n=5), 3 \mu \mathrm{M}(214 \pm 96 \%, n=6)$, and $10 \mu \mathrm{M}(347 \pm 193 \%, n=5)$, but significantly increased sEPSC frequency at $30 \mu \mathrm{M}$ (936 $\pm 553 \%, n=6$; $p<0.05$, one-way ANOVA) (Fig. $1 G$ ). The calculated $\mathrm{EC}_{50}$ was $11 \mu \mathrm{M}$. Interestingly, serotonin significantly inhibited sEPSC frequency in 2 of 5 neurons ( $p<0.05$, KS test) at $1 \mu \mathrm{M}$ and 2 of 6 neurons at $3 \mu \mathrm{M}$ (Fig. $1 G)$. No significant inhibition was seen at higher doses.

\section{$5-\mathrm{HT}_{3} \mathrm{R}$ agonists mimic the effect of serotonin on sEPSCs in TH-EGFP neurons}

To begin to determine which receptor subtype mediates the effects of serotonin, we tested agonists specific for the $5-\mathrm{HT}_{3} \mathrm{R}$. Application of the $5-\mathrm{HT}_{3} \mathrm{R}$ agonist SR57227 $(10 \mu \mathrm{M})$ increased the frequency of sEPSCs in 10 of 11 TH-EGFP neurons tested (Fig. $2 A, B, D ; p<0.05$, KS test). On average, SR57227 increased the frequency of sEPSCs from $3.3 \pm 0.7$ to $11.5 \pm 2.4 \mathrm{~Hz}$, a $331 \pm$ $46 \%$ increase over control (Fig. $2 D, n=11 ; p<0.05$, one-way ANOVA). This effect was reversed by a $10 \mathrm{~min}$ wash (ACSF), with the frequency of sEPSCs decreasing back to $3.6 \pm 0.6 \mathrm{~Hz}$ or $114 \pm$ $0.2 \%$ of control (Fig. $2 A, B$ ). The effects of SR57227 were concentration dependent, with no significant effect seen at the lower doses of $1 \mu \mathrm{M}(120 \pm 17 \%, n=4)$ and $3 \mu \mathrm{M}(124.6 \pm 29.7 \%, n=$ $6)$ and a significant increase at both 10 and $30 \mu \mathrm{M}(331 \pm 46$ and $280 \pm 53 \%, n=4$ and 6 , respectively; $p<0.05$, one-way ANOVA) (Fig. 2C). SR57227 at $6 \mu \mathrm{M}$ significantly increased sEPSC frequency compared to ACSF $(136 \pm 13 \%, n=5)$, but the effect was not significantly different from the other doses, meaning it has an intermediate effect. The calculated $\mathrm{EC}_{50}$ for SR57227 was $\sim 7 \mu \mathrm{M}$.

We next tested the effect of another $5-\mathrm{HT}_{3} \mathrm{R}$ agonist, $\mathrm{m}$-chlorophenylbiguanide (mCPBG), on glutamate inputs onto TH-EGFP neurons. mCPBG $(30 \mu \mathrm{M})$ also increased the frequency of sEPSCs in TH-EGFP neurons from $5.2 \pm 0.7$ to $30.6 \pm$ $9.6 \mathrm{~Hz}$ or $594 \pm 191 \%$ increase (Fig. $2 D, n=11 ; p<0.05$, one-way ANOVA). A 10 min wash (ACSF) of mCPBGs partially reversed this effect, with the frequency of sEPSCs reduced to $18.1 \pm 6.5 \mathrm{~Hz}$ or $411 \pm 144 \%$ of control $(n=8 ; p<0.05$, one-way ANOVA). 
A
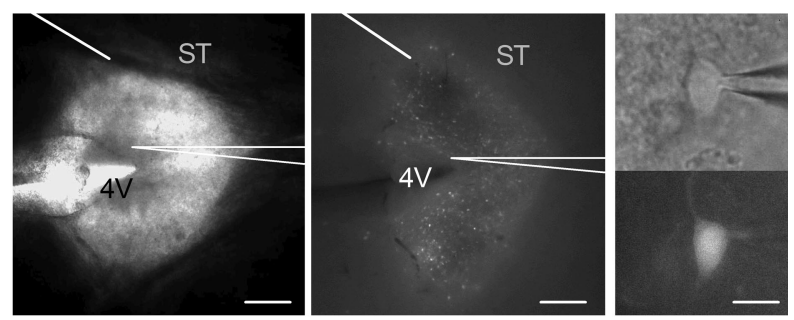

B

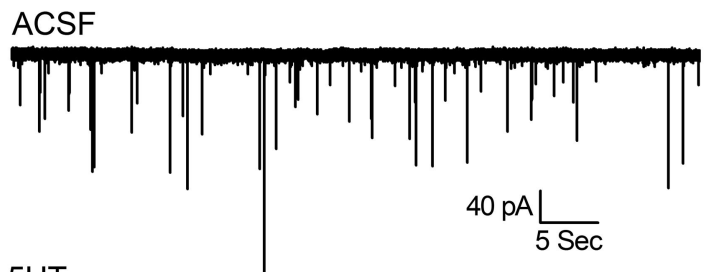

$5 \mathrm{HT}$

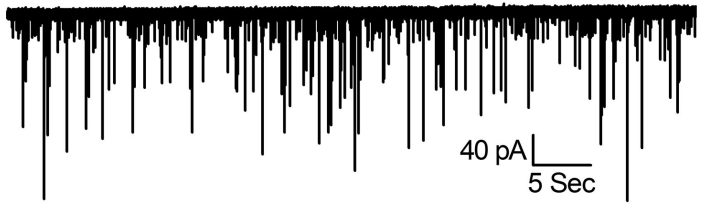

C
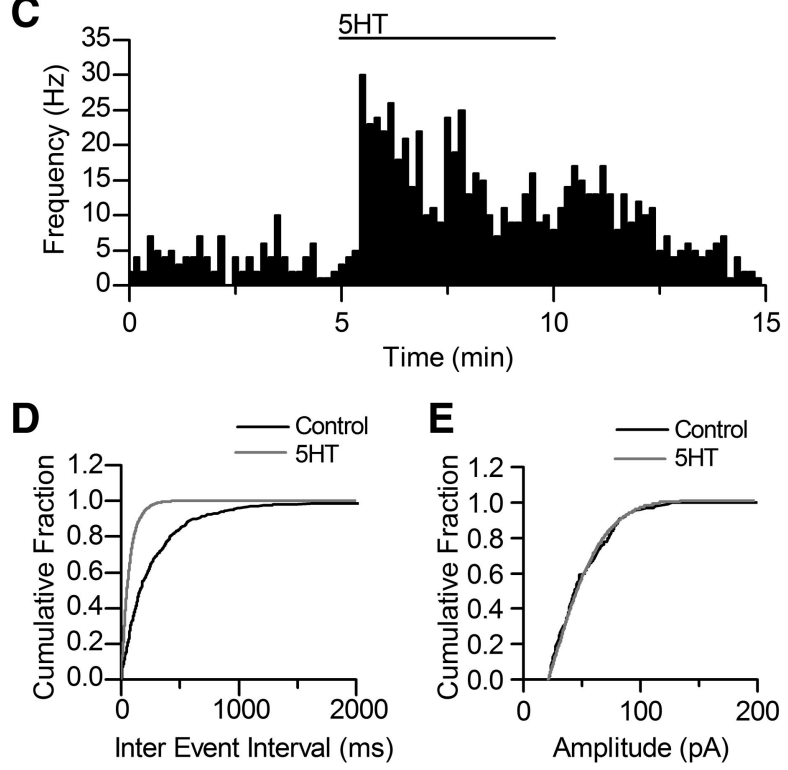

$\mathbf{F}$

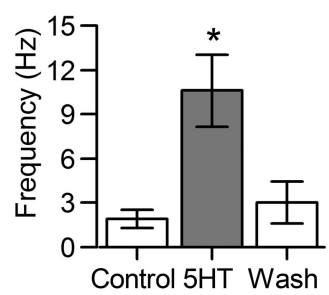

G

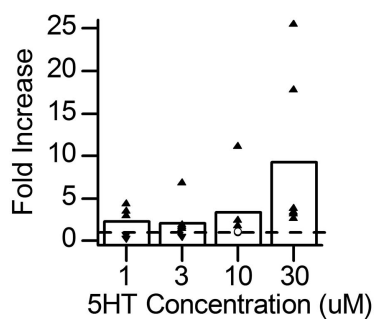

Figure 1. Serotonin increases the frequency of spontaneous glutamate EPSCs in TH-EGFP neurons. $A$, Visualization of NTS brain slice taken from a TH-EGFP mouse using DIC (left) and fluorescence (right). Scale bars, $1 \mathrm{~mm}$. $\boldsymbol{B}$, Representative (single) traces from a NTS TH-EGFP neurons during control (ACSF) and following bath application of $30 \mu \mathrm{m}$ serotonin. $\mathrm{V}_{\mathrm{m}}=-60$ $\mathrm{mV}$. C, Average frequency over time, binned into $10 \mathrm{~s}$ periods, from a TH-EGFP neuron treated with serotonin. $\boldsymbol{D}, \boldsymbol{E}$, Cumulative fraction of interevent interval $(\boldsymbol{D})$ and amplitudes $(\boldsymbol{E})$ during baseline (control) and serotonin treatment in a TH-EGFP neuron. $\boldsymbol{F}$, Average effect of serotonin on frequency of $s$ EPSCs in TH-EGFP neurons $(n=6)$. G, Dose-response curve for serotonin. Error bars indicate SEM; ${ }^{*} p<0.05$, one-way ANOVA.
$5-\mathrm{HT}_{3} \mathrm{R}$ antagonists block the effect of serotonin on sEPSCs in TH-EGFP neurons

To confirm the role of the $5-\mathrm{HT}_{3} \mathrm{R}$, we next determined whether the $5-\mathrm{HT}_{3} \mathrm{R}$ antagonist ondansetron (ODN, $0.5 \mu \mathrm{M}$ ) blocked the effects of serotonin, SR57227, and mCPBG. ODN alone did not change the frequency of sEPSCs [ control $=3.4 \pm 0.8 \mathrm{~Hz}$; ODN $=$ $3.4 \pm 0.88 \mathrm{~Hz} ; 99.8 \pm 8.9 \%$ of control (ACSF)] (Fig. $2 B, D, n=$ 11). However, ODN blocked the effects of serotonin to increase sEPSC frequency and actually revealed an inhibitory effect of serotonin on sEPSC frequency, presumably mediated by another serotonin receptor $(\mathrm{ODN}+5-\mathrm{HT}=54.0 \pm 8.2 \%$ of ODN alone, $n=5)$. ODN also blocked the increase in sEPSC frequency stimulated by the $5-\mathrm{HT}_{3} \mathrm{R}$ agonists SR57227 and mCPBG (Fig. $2 D$; SR57227 + ODN $=88.1 \pm 10.4 \%$ of ODN alone, $n=7$; and $\mathrm{mCPBG}+\mathrm{ODN}=101.3 \pm 9.0 \%$ of ODN alone, $n=5 ; p<0.05$, one-way ANOVA).

\section{Presynaptic actions of a $5-\mathrm{HT}_{3} \mathrm{R}$ agonist on}

\section{NTS-TH-EGFP neurons}

To determine whether the actions of the $5-\mathrm{HT}_{3} \mathrm{R}$ agonists are through presynaptic or postsynaptic mechanisms, we examined miniature EPSCs in the presence of $2 \mu \mathrm{M}$ TTX to block action potentials (APs) (Fig. 3). The voltage was held at $-60 \mathrm{mV}$, the approximate equilibrium potential for chloride, to isolate glutamatergic mEPSCs. In the presence of TTX, $30 \mu \mathrm{M}$ mCPBG significantly decreased the interevent interval (i.e., increased the frequency of sEPSCs) in all neurons tested ( $p<0.05$, KS test, $n=$ 5) with an average frequency of $3.16 \pm 0.58 \mathrm{~Hz}$ in TTX only to $18.2 \pm 8.3 \mathrm{~Hz}$ in TTX plus $\mathrm{mCPBG}(n=5)$, an average increase of $697 \pm 334 \%$ (Figure $3 A, B, D, p<0.05$ Student's $t$ test). In contrast, $\mathrm{mCPBG}$ had no consistent effect on mEPSC amplitude (Fig. $3 C, E$; TTX only $=-44.9 \pm 3.8 \mathrm{pA}$; TTX plus $\mathrm{mCPBG}=-42.3 \pm$ $4.3 \mathrm{pA})$. TTX did not have a significant effect on baseline EPSC frequency or baseline amplitude (Fig. 3D,E).

\section{5-HT ${ }_{3} \mathrm{R}$ agonists affect less than one third of TH-EGFP negative NTS neurons}

To determine whether activation of $5-\mathrm{HT}_{3} \mathrm{Rs}$ increased glutamate inputs onto all NTS neurons, we tested the effect of SR57227 $(10 \mu \mathrm{M})$ on sEPSCs in non-TH-EGFP neurons and found that only 2 of 9 neurons responded with a significant increase ( $p<$ 0.05 , KS test), with SR57227 increasing the sEPSC frequency to 110 and $160 \%$ compared to control (Fig. 4A). This is a significantly lower response rate than the 10 of 11 TH-EGFP neurons that responded to SR57227 ( $p<0.01$, Fishers exact test). mCPBG also only increased the basal frequency of sEPSCs in 2 of 6 nonEGFP neurons ( $p<0.05$, KS test), compared to 7 of 9 TH-EGFP neurons (Fig. $4 B$ ).

\section{MK212 and mCPP have mixed effects on SEPSC in TH- EGFP neurons}

mCPP, a non-specific serotonin receptor agonist, has been shown to activate c-fos in a subpopulation of TH positive NTS neurons in vivo (Lam et al., 2009). We therefore wanted to determine whether $\mathrm{mCPP}$ and $\mathrm{MK} 212$, a more selective $5-\mathrm{HT}_{2 \mathrm{C}} \mathrm{R}$ agonist, would also activate these neurons in vitro. $\mathrm{mCPP}(10 \mu \mathrm{M})$ increased the frequency of sEPSCs in 3 of 5 TH-EGFP neurons $(p<0.05$, KS test). The size of the increase was smaller than the average effect of SR57227 (average $\mathrm{mCPP}$ response $=147 \pm$ $11 \%, n=3$; average SR57227 response $=331 \pm 46 \%, n=9$ ). Application of MK212 (10 $\mu \mathrm{M})$, a 5- $\mathrm{HT}_{2 \mathrm{C}} \mathrm{R}$ agonist, also slightly increased the frequency of sEPSCs in 2 of 6 TH-EGFP neurons 
A

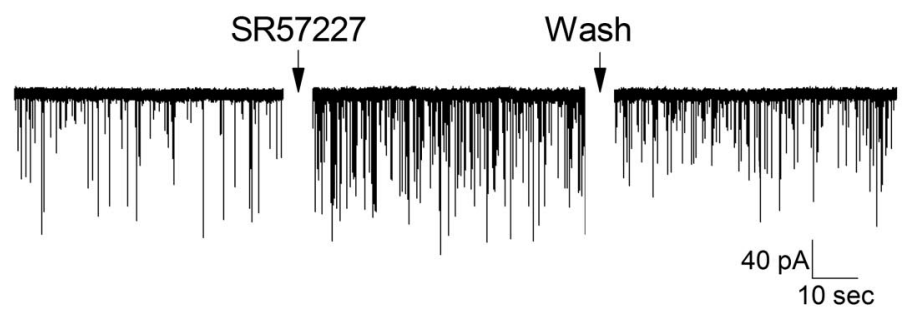

B

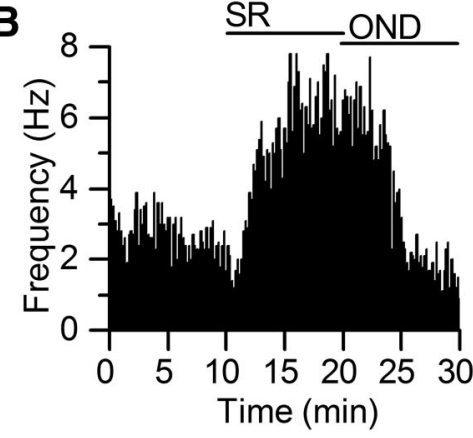

C

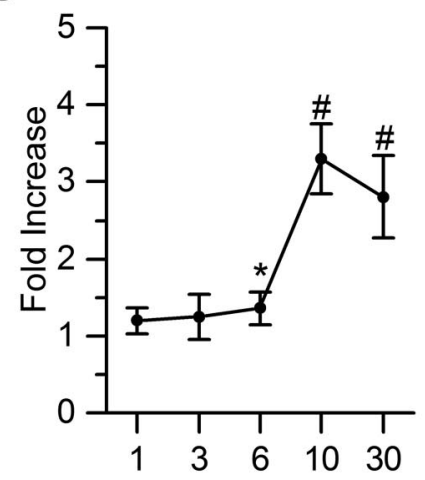

Concentration [uM]

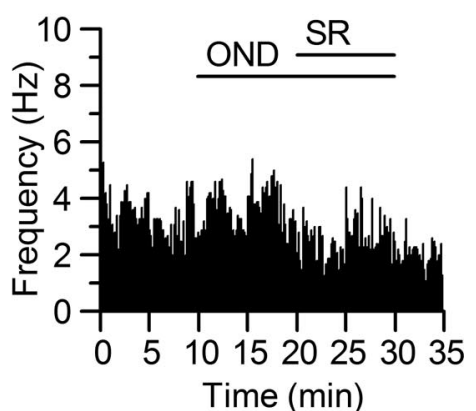

D

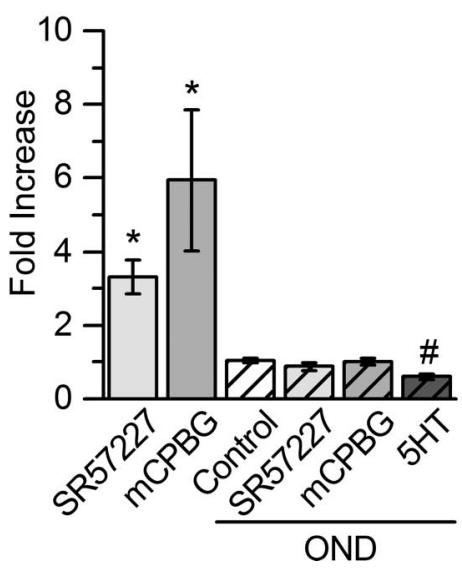

Figure 2. The effects of serotonin on spontaneous glutamate EPSCS in TH-EGFP neurons are mediated by the $5-\mathrm{HT}_{3}$ receptor. $\boldsymbol{A}$, Single representative traces from a NTS TH-EGFP neuron during control (ACSF) and following bath application of the 5 - $\mathrm{HT}_{3}$ receptor agonist SR57227. B, Average frequency over time, binned into $10 \mathrm{~s}$ periods, from a TH-EGFP neuron treated with $10 \mu \mathrm{m}$ SR57227 (SR) with and without pretreatment with the $5-\mathrm{HT}_{3}$ receptor antagonist ondansetron (OND) $(0.5 \mu \mathrm{M})$. C, Concentration response curve showing fold increase in sEPSC frequency following a 10 min exposure to SR57227. ${ }^{*} p<0.05$ compared to ACSF only; ${ }^{\#} p<$ 0.05 compared to ACSF, 1 and $3 \mu \mathrm{m}$ (one-way ANOVA). D, Bar graph showing the average fold change in sEPSC frequency stimulated by $5-\mathrm{HT}_{3}$ receptor agonists in NTS TH-EGFP neurons with and without pretreatment of ondansetron. ${ }^{*} p<0.05$ denotes a significant increase; $\# p<0.05$ denotes a significant decrease in frequency compared to ACSF (one-way ANOVA). Error bars indicate SEM.

$(p<0.05$, KS test) but caused a significant decrease in the frequency of sEPSCs in 3 of 6 neurons ( $p<0.05, \mathrm{KS}$ test).

\section{SR57227 increases the action potential firing rate of TH-EGFP neurons}

We have reported previously that altering spontaneous glutamate inputs onto NTS-TH-EGFP neurons alters their firing rate (Cui et al., 2011). We therefore wanted to determine whether activation of the $5-\mathrm{HT}_{3} \mathrm{R}$ would increase action potential firing rate of NTS-TH-EGFP neurons, as SR57227 increased the frequency of sEPSCs. Application of $10 \mu \mathrm{M}$ SR57227 increased the AP firing rate of TH-EGFP neurons from $2.0 \pm 1.0$ to $3.8 \pm 1.6 \mathrm{~Hz}$ in 7 of 8 neurons tested $(p<$ 0.05 , KS test), with an average increase of $254.4 \pm 57.2 \%$ (Fig. $5 A, B, n=7, p<0.05$, Student's $t$ test). The average resting membrane potential was $-60 \mathrm{mV}$. To test whether this in-

crease in firing was due to the increased frequency of spontaneous glutamate inputs, we tested whether NBQX, an AMPA receptor antagonist, blocked the effect of SR57227 on firing rate. Bath application of NBQX blocked the ability of SR57227 to increase AP firing rate in TH-EGFP neurons [Fig. $5 C, n=6$; control (ACSF), $1.8 \pm 0.8 \mathrm{~Hz}$; NBQX, $1.8 \pm$ $0.8 \mathrm{~Hz}$; NBQX + SR, $1.8 \pm 1.1 \mathrm{~Hz}]$.

\section{$5-\mathrm{HT}_{3} \mathrm{R}$ agonists decrease the amplitude of solitary tract-evoked EPSCs}

A major source of glutamate in the NTS is the solitary tract afferent fibers. We therefore examined whether $5-\mathrm{HT}_{3} \mathrm{R}$ agonists had any effect on the ability of the incoming visceral afferents in the ST to activate TH-EGFP neurons. Our horizontal brain slice preparation preserves a lengthy segment of the ST in the same plane as the cell bodies of NTS (Fig. 1A). This allows placement of the stimulating electrode on the visible ST at a sufficient distance from the recording area to allow activation of the ST with minimal focal activation of local glutamate neurons (Bailey et al., 2008). Brief shocks (100 $\mu$ s duration) passed through the stimulating electrode evoked EPSCs (ST-EPSCs) in TH-EGFP neurons. As we have described previously, ST-EPSCs in the TH-EGFP neurons had nearly invariant latencies, few failures, and frequency-dependent amplitude depression (Appleyard et al., 2007). As has also been previously reported (Appleyard et al., 2007) some of these ST-EPSCs were compound EPSCs comprised of EPSCs evoked by several individual ST inputs. Bath application of $10 \mu \mathrm{M}$ SR57227 significantly inhibited the amplitude of the STEPSC in all neurons tested (Fig. 6A, B), from $-460.5 \pm 75.5 \mathrm{pA}$ in ACSF to $-257.8 \pm 53.0 \mathrm{pA}$ in SR57227, an effect reversed by ondansetron to $-384.3 \pm$ 73.5 pA (Figure 6A,B) $(p<0.05$, Student's $t$ test $)(n=12)$. The range of inhibition was from 10.7 to $96.4 \%$ of control. Pretreatment with $0.5 \mu \mathrm{M}$ ondansetron also blocked the effects of SR57227 (control $=-445.2 \pm 116.2 \mathrm{pA}$ vs $\mathrm{OND}=-450.6 \pm 94.9 \mathrm{pA}, \mathrm{OND}+\mathrm{SR} 57227=-425.0 \pm 128.4$ pA) but had no effect alone on ST-EPSC amplitude (Fig. 6A, $B$, $n=5)$. SR57227 also significantly increased the paired-pulse ratio (PPR; EPSC2 amplitude/EPSC1 amplitude when two shocks were applied $20 \mathrm{~ms}$ apart), consistent with SR57227 having a presynaptic mechanism of action (PPR in control $=0.58 \pm$ 0.04, SR57227 $=0.88 \pm 0.12$, wash $=0.63 \pm 0.03$; Figure $6 A, C$, $n=10 ; p=0.05$, Student's $t$-test). The effect of SR57227 on PPR was blocked by pretreatment of ondansetron. (Control $=0.70 \pm$ $0.06, \mathrm{OND}$ alone $=0.71 \pm 0.08, \mathrm{OND}+\mathrm{SR} 57227=0.70 \pm 0.06$, wash $=0.74 \pm 0.07$ (Fig. $6 A, C)(n=5)$. Given that SR57227 increases the firing rate of the TH-EGFP neurons despite the 
A TTX only
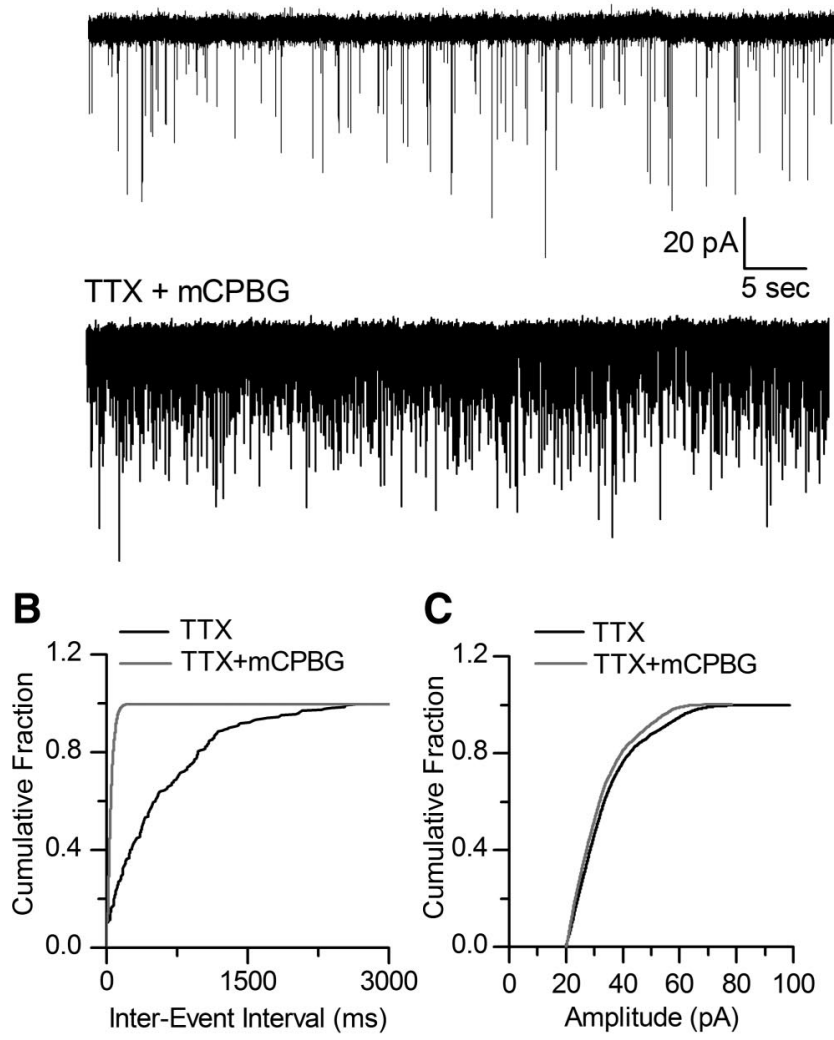

D
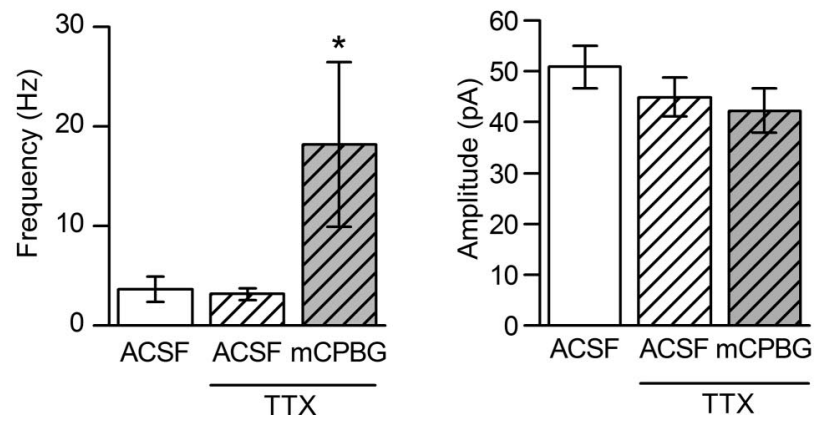

Figure 3. The $5-\mathrm{HT}_{3}$ receptor agonist $\mathrm{mCPBG}$ increase the frequency, but not the amplitude, of miniature EPSCS. A, Representative traces in the presence of TTX during control (ACSF+ TTX) and following bath application of the $5-\mathrm{HT}_{3}$ receptor agonist $\mathrm{mCPBG}(\mathrm{TTX}+\mathrm{mCPBG})$ in a THEGFP neuron. $\boldsymbol{B}, \boldsymbol{C}$, Cumulative fraction of inter-vent interval $(\boldsymbol{B})$ and amplitudes $(\boldsymbol{C})$ of $\mathrm{mEPSCS}$ in control and in $30 \mu \mathrm{m} \mathrm{mCPBG}$ in the presence of TTX from a representative TH-EGFP neuron. $\boldsymbol{D}$, Graph showing the average frequency of mEPSCs in control conditions, TTX only and TTX + mGPBG. $E$, Graph showing the average amplitude of $m E$ ESSCs in control conditions, TTX only and TTX + mGPBG $(n=5)^{*} p<0.05$, one-way ANOVA.

inhibition of the ST-EPSC inputs, it suggests that the overall effect of SR57227 is to excite NTS-TH neurons.

\section{Discussion}

Catecholamine neurons in the NTS are proposed to be important for the control of food intake (Mönnikes et al., 1997; Willing and Berthoud, 1997; Rinaman et al., 1998), reward (Smith and AstonJones, 2008; Kenny, 2011), stress responses (Schiltz and Sawchenko, 2007), cardiovascular reflexes (Simon et al., 1985; Kubo et al., 1990; Itoh and Bunag, 1993), and other homeostatic functions (Hollis et al., 2004; Ulrich-Lai and Herman, 2009). Yet little is known about how serotonin, a crucial transmitter in the con-

\section{A SR57227}

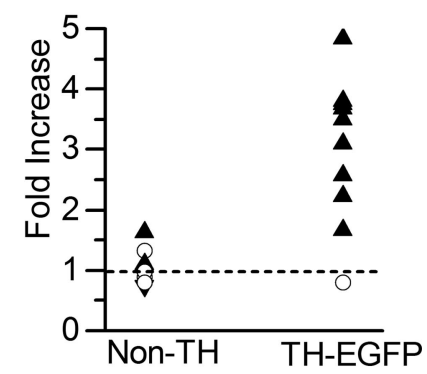

\section{B $\mathrm{mCPBG}$}

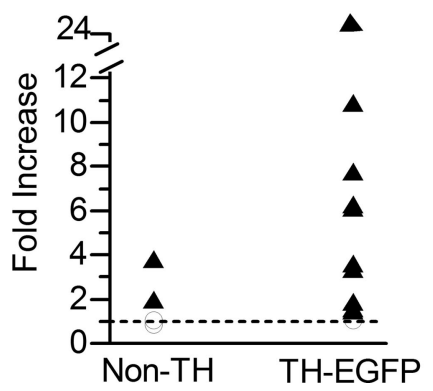

Figure 4. 5- $\mathrm{HT}_{3}$ receptor agonists have a limited effect on the frequency of sEPSCs in THnegative neurons. Scatter plots showing the fold increase or decrease in SEPSC frequency stimulated by $5-\mathrm{HT}_{3}$ receptor agonists in both TH-EGFP-negative and TH-EGFP-positive neurons. Each point represents the response in an individual neuron. $A$ shows the effect of SR57227 in TH negative neurons $(n=9)$ and TH-positive neurons $(n=11)$. $\boldsymbol{B}$ shows the effect of $\mathrm{mCPBG}$ in TH-negative neurons $(n=6)$ and TH positive neurons $(n=11)$. $\bigcirc$ denotes effect was not significant; $\boldsymbol{\Delta}$ denotes a significant increase (KS test; $p<0.05$ ); $\boldsymbol{\nabla}$ denotes a significant decrease (KS test; $p<0.05$ ).

trol of these functions, modulates these neurons. Here we report five key new findings. First, serotonin increases the excitatory glutamate tone onto NTS-TH neurons through activation of $5-\mathrm{HT}_{3} \mathrm{Rs}$. Second, 5- $\mathrm{HT}_{3} \mathrm{R}$ agonists mimic this effect in a concentration-dependent manner through a presynaptic mechanism to increase glutamate release. Third, this surge in glutamate release increases the firing rate of NTS-TH neurons, an effect blocked by the glutamate receptor antagonist NBQX. Fourth this activation does not require activation of the solitary tract. Fifth, $5-\mathrm{HT}_{3} \mathrm{R}$ agonists preferentially modulate NTS-TH neurons compared to non-TH NTS neurons.

\section{Serotonin increases the frequency of glutamate inputs onto}

NTS-TH neurons through activation of presynaptic $5-\mathrm{HT}_{3} \mathrm{Rs}$ $5-\mathrm{HT}_{3} \mathrm{Rs}$ are expressed on sensory afferent terminals (Pratt and Bowery, 1989; Leslie et al., 1990; Huang et al., 2004), as well as terminals in close proximity to catecholamine neurons (Pickel et al., 1984). Here we show that serotonin dramatically increases spontaneous glutamate EPSCs onto NTS-TH neurons through activation of $5-\mathrm{HT}_{3} \mathrm{Rs}$, as the effect is completely blocked by the $5-\mathrm{HT}_{3} \mathrm{R}$ antagonist ondansetron and mimicked by the $5-\mathrm{HT}_{3} \mathrm{R}$ agonists mCPBG and SR57227. The effects of both 5-HT and SR57227 are concentration dependent, with very steep relationships consistent with a cooperative binding relationship (Barnes et al., 1992). This demonstrates for the first time that serotonin increases the basal excitatory glutamate tone onto NTS-CA neurons. Our data support a presynaptic mechanism of action, as $5-\mathrm{HT}_{3} \mathrm{R}$ agonists increase the frequency but not the amplitude of mEPCS and have no discernible effect on post-synaptic parame- 


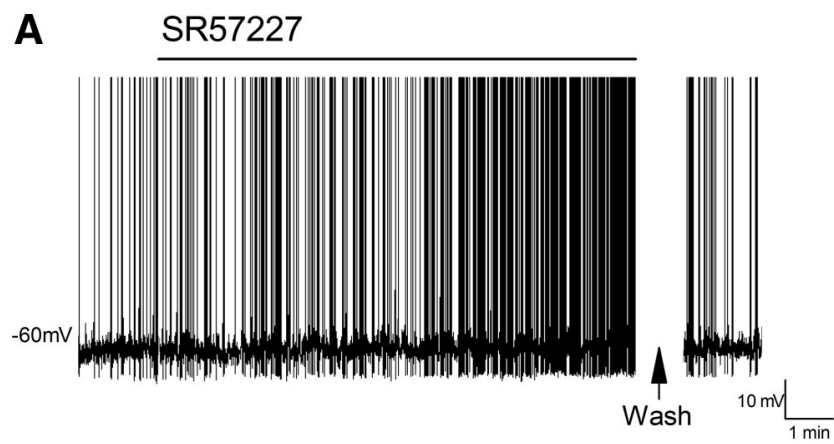

B

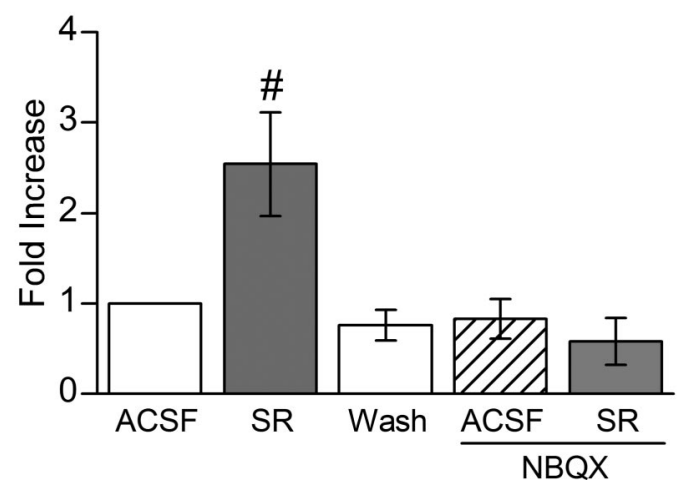

Figure 5. The $5-\mathrm{HT}_{3}$ receptor agonist SR57227 increases the firing rate of TH-EGFP neurons in a glutamate-dependent manner. $A$, Representative trace from a current-clamp experiment showing the firing rate of a TH-EGFP neuron. Bath application of $10 \mu \mathrm{m}$ SR57227 significantly increased the action potential firing rate in all six NTS TH-EGFP neurons tested. $\boldsymbol{B}$, Average fold increase in action potential firing rate in NTS-EGFP neurons compared to baseline (ACSF/control) following SR57227 (SR) treatment and wash $(n=6)$ and in the presence of the inotropic glutamate antagonist $20 \mu \mathrm{m}$ NBQX, SR57227 + NBQX and following wash (in NBQX only) in NTS TH-EGFP neurons $(n=6)$. Error bars indicate SEM; ${ }^{*} p<0.01$, one-way ANOVA.

ters. Interestingly, serotonin inhibited sEPSC frequency in the presence of ondansetron, suggesting other 5-HT receptors inhibit glutamate release. $5-\mathrm{HT}_{1 \mathrm{D}}$ Rs are present in the NTS, and their activation inhibits NTS neuronal discharge in vivo (Jeggo et al., 2007). We found the $5-\mathrm{HT}_{2 \mathrm{C}} \mathrm{R}$ agonist, MK212, inhibits glutamate inputs onto $50 \%$ of CA neurons. Low concentrations of serotonin also inhibit inputs onto $50 \%$ of CA neurons, potentially due to its higher affinity for $5-\mathrm{HT}_{2 \mathrm{C}}$ Rs and $5-\mathrm{HT}_{1 \mathrm{D}} \mathrm{Rs}$ than for $5-\mathrm{HT}_{3} \mathrm{Rs}$ (Olivier et al., 1997) and suggesting the intriguing possibility of differential effects of serotonin depending on its concentration and site of release.

\section{5- $\mathrm{HT}_{3} \mathrm{R}$ activation decreases afferent activation of NTS-TH-EGFP neurons}

In contrast to their effect to increase spontaneous glutamate inputs, we found that $5-\mathrm{HT}_{3} \mathrm{R}$ agonists decrease the amplitude of ST-EPSCs in NTS-TH neurons. One explanation is that activation of $5-\mathrm{HT}_{3}$ Rs causes such a large increase in spontaneous glutamate release that the readily releasable vesicle pool is depleted; therefore, less glutamate is available during ST stimulation, and the amplitude of the evoked EPSC is decreased. This mechanism is proposed to underlie the effects of the VR1 agonist capsaicin, which also increases sEPSC frequency while attenuating STEPSC amplitude in NTS neurons (Doyle et al., 2002; Peters et al., 2010). Multiple lines of evidence support this model. First, $5-\mathrm{HT}_{3} \mathrm{Rs}$ are ligand-gated cation channels that are generally excitatory and increase the probability of transmitter release (Funahashi et al., 2004; Derkach et al., 1989; Machu, 2011). Sec-
A
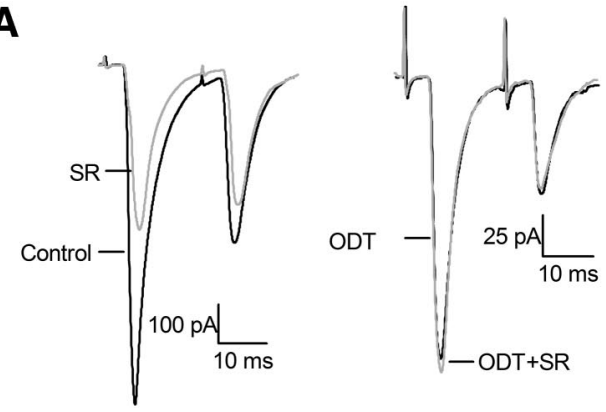

B
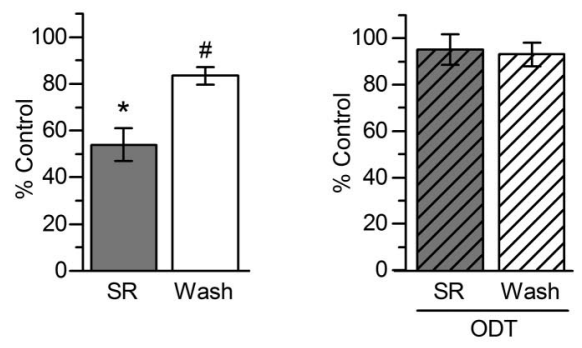

C
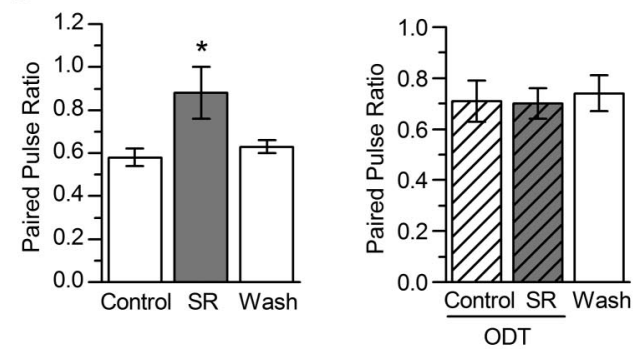

Figure 6. The 5- $\mathrm{HT}_{3}$ receptor agonist SR57227 (SR) $(10 \mu \mathrm{m})$ significantly decreases the amplitude of ST-EPSCs in TH-EGFP neurons. $A$, Representative trace of two ST-stimulated EPSCS. ST activation evoked monosynaptic EPSCS in TH-EGFP neurons (Jitter or SD of latency $<200$ $\mu \mathrm{sec}$ ). $\mathrm{V}_{\mathrm{m}^{\prime}}-60 \mathrm{mV}$. SR57227 significantly inhibited the amplitude of the ST stimulated EPSCS. This effect was reversed after a 10 min wash. $B$, A graph showing the average inhibition of effect of ST-EPCS amplitude by SR57227 and following a 10 min wash in TH-EGFP neurons in control conditions (left) and in the presence of the $5-\mathrm{HT}_{3}$ receptor antagonist ondansetron (ODT) $(0.5$ $\mu \mathrm{M})$. C, A graph showing the paired pulse ratio in ACSF following bath application of SR57227 and following a $10 \mathrm{~min}$ wash in control conditions (left) and in the presence of ondansetron (10 $\mu \mathrm{M}$, right) in TH-EGFP neurons $(n=12)$. Error bars indicate SEM; ${ }^{*} p<0.05$, one-way ANOVA.

ond, activation of $5-\mathrm{HT}_{3} \mathrm{Rs}$ depolarizes nodose ganglia neurons (ST afferent cell bodies) (Higashi and Nishi, 1982), increases vagal afferent firing (Niijima, 1981; Blackshaw and Grundy, 1993), and potentiates vagal activation of NTS neurons (Jeggo et al., 2005), suggesting they have excitatory effects on afferents. Third, $5-\mathrm{HT}_{3} \mathrm{R}$ antagonists decrease both vagal activation of NTS neurons (Jeggo et al., 2005) and the probability of glutamate release from afferent terminals (Wan and Browning, 2008), consistent with serotonin normally increasing glutamate release. Taken together with our findings, these data suggest that serotonin activates NTS-TH neurons, at least in part by releasing glutamate from ST afferents. Interestingly, we see no effect of the $5-\mathrm{HT}_{3} \mathrm{R}$ antagonist in our horizontal slices, suggesting we have lost an endogenous serotonin tone maintained in coronal slices that preserve inputs from raphe nuclei (Wan and Browning, 2008).

Serotonin increases firing rate of NTS-TH neurons indirectly by increasing excitatory glutamate inputs

Transmitters and hormones can dynamically adjust the firing threshold of neurons by altering spontaneous glutamate inputs 
(Lee et al., 2010; Sutton et al., 2006), including NTS-TH neurons (Cui et al., 2011). SR57227 increased the firing rate of NTS-TH neurons in an AMPAR-dependent manner; suggesting that activation of $5-\mathrm{HT}_{3} \mathrm{Rs}$ increases NTS-TH neuronal firing indirectly by increasing glutamate tone. Furthermore, serotonin increases glutamate release independently of afferent activation, indicating that serotonin can activate NTS-TH neurons even in the absence vagal feedback.

\section{Serotonin preferentially effects catecholamine over noncatecholamine neurons in the NTS}

In contrast to the almost universal responsiveness of NTS-TH neurons to serotonin, less than one-third of non-TH NTS neurons respond to $5-\mathrm{HT}_{3} \mathrm{R}$ agonists, and the size of the responses was considerably smaller than that in catecholamine neurons. This identifies TH neurons as an important subpopulation of NTS neurons that are activated by serotonin. $5-\mathrm{HT}_{3} \mathrm{Rs}$ in the NTS contribute to the control of meal size (Hayes and Covasa, 2006b) and modulate cardiovascular reflexes (Merahi et al., 1992; SévozCouche et al., 2003; Jeggo et al., 2005), suggesting that they have an important action on homeostatic functions. NTS $5-\mathrm{HT}_{3} \mathrm{Rs}$ are also critical for the severe anorexia induced by ablation of NPY neurons in the arcuate nucleus of the hypothalamus (ARC) (Wu et al., 2012). A glutamatergic projection from the NTS to the parabrachial nucleus $(\mathrm{PB})$ is similarly required for this anorexia. As norepinephrine (NE) is released locally in the NTS (AlKhrasani et al., 2003; Arakawa et al., 1991), it is possible that activation of $5-\mathrm{HT}_{3} \mathrm{Rs}$ increases NE release, which then activates NTS glutamate neurons projecting to the $\mathrm{PB}$. Alternatively, some of the NTS-TH neurons or the $30 \%$ of non-TH neurons that respond to $5-\mathrm{HT}_{3} \mathrm{R}$ activation could be glutamatergic. The degree of the anorexia seen with activation of $5-\mathrm{HT}_{3} \mathrm{Rs}$ in the NTS and the use of $5-\mathrm{HT}_{3} \mathrm{R}$ antagonists to treat nausea clinically (Machu, 2011) suggest that their effects on food intake may be protective through eliciting nausea to non-nutritive/poisonous food.

\section{Physiological implications for serotonin activating NTS- TH neurons}

NTS-CA neurons make extensive projections to many nuclei, including the hypothalamus, nucleus accumbens, and the dorsal motor nucleus of the vagus nerve or DMNV (Cunningham and Sawchenko, 1988; Wang et al., 1992; Rogers et al., 2003; Reyes and Van Bockstaele, 2006; Rinaman, 2011). Our finding that serotonin activates $>90 \%$ of NTS-TH neurons predicts that serotonin would cause an increase in catecholamine release at most of these sites. NTS-CA neurons participate in neuronal circuits that widely influence homeostasis and behaviors including food intake, reward, anxiety, stress, and cardiovascular reflexes (Lacroix and Rivest, 1997; Chan and Sawchenko, 1998; Van Bockstaele et al., 2001; Laorden et al., 2002; Krout et al., 2005). Therefore, our results elucidate a mechanism by which serotonin could influence catecholamine modulation of these behaviors and functions.

Afferent terminals in the NTS that directly activate NTS-TH neurons are responsive to several signals that modulate food intake and other homeostatic functions, including cholecystokinin or CCK (Appleyard et al., 2007), ghrelin (Cui et al., 2011) and opioids (Cui et al., 2012). This suggests a model in which the ST afferent terminals themselves integrate humoral signals, resulting in different amounts of glutamate release and activation of NTS-TH neurons. Such an integrative capacity has already been proposed for the vagus (Browning and Travagli, 2010; Dockray, 2009).

\section{Endogenous source of serotonin}

Serotonin-positive nerve terminals are found throughout the medial NTS (Steinbush, 1981), including in close proximity with NTS-CA neurons (Pickel et al., 1984). Neurons in caudal raphe nuclei project to the NTS (Thor and Helke, 1989), and stimulation of caudal raphe nuclei releases serotonin in the NTS (Brodin et al., 1990; Weissheimer and Machado, 2007); furthermore, this projection is required for the anorexia induced by ablation of ARC-NPY (arcuate nucleus-neuropeptide Y) neurons (Wu et al., 2012). Serotonin is synthesized in some afferents (Hery et al., 1986), providing another source of serotonin in the NTS. $5-\mathrm{HT}_{3} \mathrm{Rs}$ are synthesized in nodose ganglia neurons and trafficked to terminals in both the NTS and the gut (Li, 2007); therefore, afferents modulated by serotonin centrally are also likely to respond to serotonin in the gut. The gut is a major source of serotonin, where it regulates GI function and increases vagal afferent feedback (Cirillo et al., 2011). As we found, all NTS-TH neurons receive direct inputs from serotonin-sensitive afferents; another implication of our findings is that NTS-TH neurons are potentially a downstream target of afferents that respond to GI serotonin.

In summary, our data shows that serotonin, through activation of $5-\mathrm{HT}_{3}$ receptors, strongly and broadly excite NTS-TH neurons through a presynaptic mechanism to increase glutamate release and action potential generation. This effect is relatively selective to NTS-TH neurons and is independent of vagal afferent activation. These results demonstrate a potential mechanism by which serotonin could activate NTS-CA neurons to increase release of catecholamines at multiple target nuclei and influence behaviors such as food intake, motivation, stress, and cardiovascular function.

\section{References}

Al-Khrasani M, Elor G, Yusuf Abbas M, Rónai AZ (2003) The effect of endomorphins on the release of ${ }^{3} \mathrm{H}$-norepinephrine from rat nucleus tractus solitarii slices. Regul Pept 111:97-101. CrossRef Medline

Andresen MC, Kunze DL (1994) Nucleus tractus solitarius-gateway to neural circulatory control. Annu Rev Physiol 56:93-116. CrossRef Medline

Appleyard SM, Marks D, Kobayashi K, Okano H, Low MJ, Andresen MC (2007) Visceral afferents directly activate catecholamine neurons in the solitary tract nucleus. J Neurosci 27:13292-13302. CrossRef Medline

Arakawa K, De Jong W, Mulder AH, Versteeg DH (1991) The electrically stimulated release of $\left[{ }^{3} \mathrm{H}\right]$ noradrenaline from nucleus tractus solitarii slices in vitro is modulated via mu-opioid receptors. Eur J Pharmacol 192:311-316. CrossRef Medline

Bailey TW, Appleyard SM, Jin YH, Andresen MC (2008) Organization and properties of GABAergic neurons in solitary tract nucleus (NTS). J Neurophysiol 99:1712-1722. CrossRef Medline

Balcita-Pedicino JJ, Rinaman L (2007) Noradrenergic axon terminals contact gastric preautonomic neurons in the paraventricular nucleus of the hypothalamus in rats. J Comp Neurol 501:608-618. CrossRef Medline

Barnes JM, Barnes NM, Costall B, Jagger SM, Naylor RJ, Robertson DW, Roe SY (1992) Agonist interactions with 5-HT3 receptor recognition sites in the rat entorhinal cortex labelled by structurally diverse radioligands. Br J Pharmacol 105:500-504. CrossRef Medline

Berthoud HR (2008) Vagal and hormonal gut-brain communication: from satiation to satisfaction. Neurogastroenterol Motil (Suppl 1):64-72. CrossRef Medline

Blackshaw LA, Grundy D (1993) Effects of 5-hydroxytryptamine (5-HT) on the discharge of vagal mechanoreceptors and motility in the upper gastrointestinal tract of the ferret. J Auton Nerv Syst 45:51-59. CrossRef

Blevins JE, Chelikani PK, Haver AC, Reidelberger RD (2008) PYY(3-36) induces Fos in the arcuate nucleus and in both catecholaminergic and non-catecholaminergic neurons in the nucleus tractus solitarius of rats. Peptides 29:112-119. CrossRef Medline

Brodin E, Linderoth B, Goiny M, Yamamoto Y, Gazelius B, Millhorn DE, Hökfelt T, Ungerstedt U (1990) In vivo release of serotonin in cat dorsal 
vagal complex and cervical ventral horn induced by electrical stimulation of the medullary raphe nuclei. Brain Res 535:227-236. CrossRef Medline

Browning KN, Travagli RA (2010) Plasticity of vagal brainstem circuits in the control of gastric function. Neurogastroenterol Motil 11:1154-1163. CrossRef Medline

Chan RK, Sawchenko PE (1998) Organization and transmitter specificity of medullary neurons activated by sustained hypertension: implications for understanding baroreceptor reflex circuitry. J Neurosci 18:371-387. Medline

Cirillo C, Vanden Berghe P, Tack J (2011) Role of serotonin in gastrointestinal physiology and pathology. Minerva Endocrinologica 36:311-324. Medline

Cole RL, Sawchenko PE (2002) Neurotransmitter regulation of cellular activation and neuropeptide gene expression in the paraventricular nucleus of the hypothalamus. J Neurosci 22:959-969. Medline

Cui RJ, Li X, Appleyard SM (2011) Ghrelin inhibits visceral afferent activation of catecholamine neurons in the solitary tract nucleus. J Neurosci 31:3484-3492. CrossRef Medline

Cui RJ, Roberts BL, Zhao H, Andresen MC, Appleyard SM (2012) Opioids inhibit visceral afferent activation of catecholamine neurons in the solitary tract nucleus. Neuroscience 222:181-190. CrossRef Medline

Cunningham ET Jr, Sawchenko PE (1988) Anatomical specificity of noradrenergic inputs to the paraventricular and supraoptic nuclei of the rat hypothalamus. J Comp Neurol 274:60-76. CrossRef Medline

Derkach V, Surprenant A, North RA (1989) 5-HT3 receptors are membrane ion channels. Nature 339:706-709. CrossRef Medline

Dockray GJ (2009) The versatility of the vagus. Physiol Behav 97:531-536. CrossRef Medline

Doyle MW, Bailey TW, Jin YH, Andresen MC (2002) Vanilloid receptors presynaptically modulate cranial visceral afferent synaptic transmission in nucleus tractus solitarius. J Neurosci 22:8222-8229. Medline

Funahashi M, Mitoh Y, Matsuo R (2004) Activation of presynaptic 5-HT3 receptors facilitates glutamatergic synaptic inputs to area postrema neurons in rat brain slices. Methods Find Exp Clin Pharmacol 26:615-622. CrossRef Medline

Glaum SR, Brooks PA, Spyer KM, Miller RJ (1992) 5-Hydroxytryptamine-3 receptors modulate synaptic activity in the rat nucleus tractus solitarius in vitro. Brain Res 589:62-68. CrossRef Medline

Grill HJ, Hayes MR (2009) The nucleus tractus solitarius: a portal for visceral afferent signal processing, energy status assessment and integration of their combined effects on food intake. Int J Obes (Lond) 33 [Suppl 1]:S11-S15. CrossRef Medline

Hayes MR, Covasa M (2006a) Gastric distension enhances CCK-induced Fos-like immunoreactivity in the dorsal hindbrain by activating 5 -HT3 receptors. Brain Res 1088:120-130. CrossRef Medline

Hayes MR, Covasa M (2006b) Dorsal hindbrain 5-HT3 receptors participate in control of meal size and mediate CCK-induced satiation. Brain Res 1103:99-107. CrossRef Medline

Hery F, Faudon M, Fueri C (1986) Release of serotonin in structures containing serotoninergic nerve cell bodies: dorsalis raphe nucleus and nodose ganglia of the cat. Ann NY Acad Sci 473:239-255. CrossRef Medline

Higashi H, Nishi S (1982) 5-Hydroxytryptamine receptors of visceral primary afferent neurones on rabbit nodose ganglia. J Physiol 323:543-567. Medline

Hollis JH, Lightman SL, Lowry CA (2004) Integration of systemic and visceral sensory information by medullary catecholaminergic systems during peripheral inflammation. Ann NY Acad Sci 1018:71-75. CrossRef Medline

Huang J, Spier AD, Pickel VM (2004) 5-HT3A receptor subunits in the rat medial nucleus of the solitary tract: subcellular distribution and relation to the serotonin transporter. Brain Res 1028:156-169. CrossRef Medline

Itoh H, Buñag RD (1993) Age-related reduction of reflex bradycardia in conscious rats by catecholaminergic nucleus tractus solitarius lesions. Mech Ageing Dev 67:47-63. CrossRef Medline

Jeggo RD, Kellett DO, Wang Y, Ramage AG, Jordan D (2005) The role of central 5-HT3 receptors in vagal reflex inputs to neurones in the nucleus tractus solitarius of anaesthetized rats. J Physiol 566:939-953. CrossRef Medline

Jeggo RD, Wang Y, Jordan D, Ramage AG (2007) Activation of 5-HT1B and 5-HT1D receptors in the rat nucleus tractus solitarius: opposing action on neurones that receive an excitatory vagal C-fibre afferent input. Br J Pharmacol 150:987-995. CrossRef Medline
Jin GR, Rao ZR, Shi JW (1994) Visceral noxious stimulation induced expression of Fos protein in medullary catecholaminergic neurons projecting to nucleus accumbens in the rat: a study with triple labeling method of HRP tracing combined with Fos and TH immunohistochemistry. Brain Res 648:196-202. CrossRef Medline

Jordan D (2005) Vagal control of the heart: central serotonergic (5-HT) mechanisms. Exp Physiol 90:175-181. CrossRef Medline

Kenny PJ (2011) Common cellular and molecular mechanisms in obesity and drug addiction. Nat Rev Neurosci 12:638-651. CrossRef

Krout KE, Mettenleiter TC, Karpitskiy V, Nguyen XV, Loewy AD (2005) CNS neurons with links to both mood-related cortex and sympathetic nervous system. Brain Res 1050:199-202. CrossRef Medline

Kubo T, Goshima Y, Hata H, Misu Y (1990) Evidence that endogenous catecholamines are involved in alpha 2-adrenoceptor-mediated modulation of the aortic baroreceptor reflex in the nucleus tractus solitarii of the rat. Brain Res 526:313-317. CrossRef Medline

Lacroix S, Rivest S (1997) Functional circuitry in the brain of immunechallenged rats: partial involvement of prostaglandins. J Comp Neurol 387:307-324. CrossRef Medline

Lam DD, Zhou L, Vegge A, Xiu PY, Christensen BT, Osundiji MA, Yueh CY, Evans ML, Heisler LK (2009) Distribution and neurochemical characterization of neurons within the nucleus of the solitary tract responsive to serotonin agonist-induced hypophagia. Behav Brain Res 196:139-143. CrossRef Medline

Laorden ML, Fuertes G, González-Cuello A, Milanés MV (2000) Changes in catecholaminergic pathways innervating paraventricular nucleus and pituitary-adrenal axis response during morphine dependence: implication of alpha(1)- and alpha(2)-adrenoceptors. J Pharmacol Exp Ther 293: 578-584. Medline

Laorden ML, Castells MT, Milanés MV (2002) Effects of morphine and morphine withdrawal on brainstem neurons innervating hypothalamic nuclei that control the pituitary-adrenocortical axis in rats. Br J Pharmacol 136:67-75. CrossRef Medline

Lee MC, Yasuda R, Ehlers MD (2010) Metaplasticity at single glutamatergic synapses. Neuron 66:859-870. CrossRef Medline

Leibowitz SF, Sladek C, Spencer L, Tempel D (1988) Neuropeptide Y, epinephrine and norepinephrine in the paraventricular nucleus: stimulation of feeding and the release of corticosterone, vasopressin and glucose. Brain Res Bull 21:905-912. CrossRef Medline

Leslie RA, Reynolds DJ, Andrews PL, Grahame-Smith DG, Davis CJ, Harvey JM (1990) Evidence for presynaptic 5-hydroxytryptamine3 recognition sites on vagal afferent terminals in the brainstem of the ferret. Neuroscience 38:667-673. CrossRef Medline

Li Y (2007) Sensory signal transduction in the vagal primary afferent neurons. Curr Med Chem 14:2554-2563. CrossRef Medline

Machu TK (2011) Therapeutics of 5-HT3 receptor antagonists: current uses and future directions. Pharmacol Ther 130:338-347. CrossRef Medline

Merahi N, Orer HS, Laporte AM, Gozlan H, Hamon M, Laguzzi R (1992) Baroreceptor reflex inhibition induced by the stimulation of serotonin 3 receptors in the nucleus tractus solitarius of the rat. Neuroscience 46:91100. CrossRef Medline

Mönnikes H, Lauer G, Arnold R (1997) Peripheral administration of cholecystokinin activates c-fos expression in the locus coeruleus/subcoeruleus nucleus, dorsal vagal complex and paraventricular nucleus via capsaicinsensitive vagal afferents and CCK-A receptors in the rat. Brain Res 770: 277-288. CrossRef Medline

Niijima A (1981) Visceral afferents and metabolic function. Diabetologia 20 (Suppl):325-330. CrossRef Medline

Olivier B, Van Wijngaarden I, Soudijn W (1997) Serotonin receptors and their ligands. Amsterdam: Elsevier.

Olson VG, Heusner CL, Bland RJ, During MJ, Weinshenker D, Palmiter RD (2006) Role of noradrenergic signaling by the nucleus tractus solitarius in mediating opiate reward. Science 311:1017-1020. CrossRef Medline

Peters JH, McDougall SJ, Fawley JA, Smith SM, Andresen MC (2010) Primary afferent activation of thermosensitive TRPV1 triggers asynchronous glutamate release at central neurons. Neuron 65:657-669. CrossRef Medline

Petrov T, Krukoff TL, Jhamandas JH (1993) Branching projections of catecholaminergic brainstem neurons to the paraventricular hypothalamic nucleus and the central nucleus of the amygdala in the rat. Brain Res 609:81-92. CrossRef Medline

Pickel VM, Joh TH, Chan J, Beaudet A (1984) Serotoninergic terminals: 
ultrastructure and synaptic interaction with catecholamine-containing neurons in the medial nuclei of the solitary tracts. J Comp Neurol 225: 291-301. CrossRef Medline

Pratt GD, Bowery NG (1989) The 5-HT3 receptor ligand, [ $\left.{ }^{3} \mathrm{H}\right]$ BRL 43694, binds to presynaptic sites in the nucleus tractus solitarius of the rat. Neuropharmacology 28:1367-1376. CrossRef Medline

Ramage AG, Villalón CM (2008) 5-hydroxytryptamine and cardiovascular regulation. Trends Pharmacol Sci 29:472-481. CrossRef Medline

Raul L (2003) Serotonin2 receptors in the nucleus tractus solitarius: characterization and role in the baroreceptor reflex arc. Cell Mol Neurobiol 23:709-726. Medline

Reyes BA, Van Bockstaele EJ (2006) Divergent projections of catecholaminergic neurons in the nucleus of the solitary tract to limbic forebrain and medullary autonomic brain regions. Brain Res 1117:69-79. CrossRef Medline

Riche D, De Pommery J, Menetrey D (1990) Neuropeptides and catecholamines in efferent projections of the nuclei of the solitary tract in the rat. J Comp Neurol 293:399-424. CrossRef Medline

Rinaman L (2011) Hindbrain noradrenergic A2 neurons: diverse roles in autonomic, endocrine, cognitive, and behavioral functions. Am J Physiol 300:R222-R235.

Rinaman L, Baker EA, Hoffman GE, Stricker EM, Verbalis JG (1998) Medullary c-Fos activation in rats after ingestion of a satiating meal. Am J Physiol 275:R262-R268. Medline

Rogers RC, Travagli RA, Hermann GE (2003) Noradrenergic neurons in the rat solitary nucleus participate in the esophageal-gastric relaxation reflex. Am J Physiol Regul Integr Comp Physiol 285:R479-R489. CrossRef Medline

Saper CB (2002) The central autonomic nervous system: conscious visceral perception and autonomic pattern generation. Annu Rev Neurosci 25: 433-469. CrossRef Medline

Sawchenko PE, Swanson LW (1981) Central noradrenergic pathways for the integration of hypothalamic neuroendocrine and autonomic responses. Science 214:685-687. CrossRef Medline

Schiltz JC, Sawchenko PE (2007) Specificity and generality of the involvement of catecholaminergic afferents in hypothalamic responses to immune insults. J Comp Neurol 502:455-467. CrossRef Medline

Sévoz-Couche C, Comet MA, Hamon M, Laguzzi R (2003) Role of nucleus tractus solitarius 5-HT3 receptors in the defense reaction-induced inhibition of the aortic baroreflex in rats. J Neurophysiol 90:2521-2530. CrossRef Medline

Simon OR, Basuray BN, West WL, Copeland R (1985) Interaction between the baroreflex and anterior hypothalamic stimulation: demonstration of a noradrenergic involvement. Neuropharmacology 24:665-675. CrossRef Medline

Smith RJ, Aston-Jones G (2008) Noradrenergic transmission in the extended amygdala: role in increased drug-seeking and relapse during protracted drug abstinence. Brain Struct Funct 213:43-61. CrossRef Medline

Steinbush HWM (1981) Distribution of serotonin-immunoreactivity in the central nervous system of the rat-cell bodies and terminals. Neuroscience 6:557-618. CrossRef Medline

Sutton MA, Ito HT, Cressy P, KempfC, Woo JC, Schuman EM (2006) Miniature neurotransmission stabilizes synaptic function via tonic suppression of local dendritic protein synthesis. Cell 125:785-799. CrossRef Medline

Takenaka R, Ohi Y, Haji A (2011) Distinct modulatory effects of 5-HT on excitatory synaptic transmissions in the nucleus tractus solitarius of the rat. Eur J Pharmacol 671:45-52. CrossRef Medline

Thor KB, Helke CJ (1989) Serotonin and substance P colocalization in medullary projections to the nucleus tractus solitarius: dual-colour immunohistochemistry combined with retrograde tracing. J Chem Neuroanat 2:139-148. Medline

Travagli RA, Hermann GE, Browning KN, Rogers RC (2006) Brainstem circuits regulating gastric function. Annu Rev Physiol 68:279-305. CrossRef Medline

Ueta Y, Kannan H, Higuchi T, Negoro H, Yamaguchi K, Yamashita H (2000) Activation of gastric afferents increases noradrenaline release in the paraventricular nucleus and plasma oxytocin level. J Auton Nerv Sys 78:6976. CrossRef Medline

Ulrich-Lai YM, Herman JP (2009) Neural regulation of endocrine and autonomic stress responses. Nat Rev Neurosci 10:397-409. CrossRef Medline

Van Bockstaele EJ, Menko AS, Drolet G (2001) Neuroadaptive responses in brainstem noradrenergic nuclei following chronic morphine exposure. Mol Neurobiol 23:155-171. CrossRef Medline

Wan S, Browning KN (2008) Glucose increases synaptic transmission from vagal afferent central nerve terminals via modulation of 5-HT3 receptors. Am J Physiol Gatrointest Liver Physiol 295:G1050-G1057. CrossRef Medline

Wang ZJ, Rao ZR, Shi JW (1992) Tyrosine hydroxylase-, neurotensin-, or cholecystokinin-containing neurons in the nucleus tractus solitarii send projection fibers to the nucleus accumbens in the rat. Brain Res 578:347350. CrossRef Medline

Weissheimer KV, Machado BH (2007) Inhibitory modulation of chemoreflex bradycardia by stimulation of the nucleus raphe obscurus is mediated by 5 -HT3 receptors in the NTS of awake rats. Autonom Neurosci 132:2736. CrossRef Medline

Williams DL, Schwartz MW, Bastian LS, Blevins JE, Baskin DG (2008) Immunocytochemistry and laser capture microdissection for realtime quantitative PCR identify hindbrain neurons activated by interaction between leptin and cholecystokinin. J Histochem Cytochem 56:285-293. CrossRef Medline

Willing AE, Berthoud HR (1997) Gastric distension-induced c-fos expression in catecholaminergic neurons of rat dorsal vagal complex. Am J Physiol 272:R59-R67. Medline

Wu Q, Clark MS, Palmiter RD (2012) Deciphering a neuronal circuit that mediates appetite. Nature 483:594-597. CrossRef Medline 